\title{
The Place of Academic English in Scientific Discourse
}

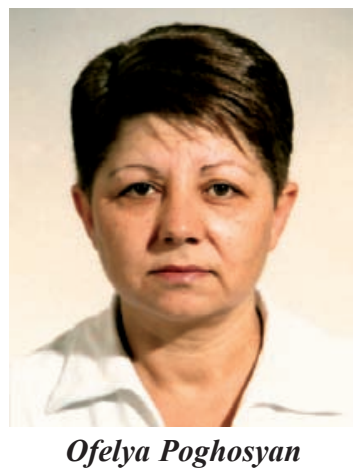
language of science' - English used for academic purposes - is bound to become international. The present article aims at discussing some problems concerning international scientific discourse.

It is a well-known fact that a language is rule-governed. That is, when we speak or write, we must follow rules guiding pronunciation, grammar and vocabulary as well as more specialized rules for communicating in a specialized sphere. Such kind of specialized sphere, for example, is science, where rules or conventions evolve over time, in response to new pressures and needs. Sometimes writers make conscious decisions to change or add new rules for written communication that will ensure greater efficiency and clarity. These linguistic or discursive rules develop over time as a result of cultural norms and internal/external pressures. For example, the experimental article, as C. Reeves states, has shortened and become more technical, losing the narrative or 'storytelling' voice of its earliest forms. ${ }^{2}$

Thus, today's 'scientific discourse' which is the result of some objective influences differs in quality from that of the earliest times. For example, judging by the analyses of the linguistic characteristics of some texts from the scientific papers of the XVII century, it can be stated that in earlier texts of 'scientific discourse' the first-person pronoun 'I' was used very often, but at present such cases are replaced by the plural first-person pronoun 'we' to avoid more personal and subjective tone in the text. The use of the plural first-person pronoun 'we' in scientific texts signals collaboration which may be effective if communication among scholars is realized with the help of international scientific discourse. With respect to pronoun 'we', it can be concluded that besides creating a more polite and restrained tone in texts of 'scientific discourse', this pronoun also acquires an ability to unite co-thinkers psychologically. Thus, changes of psycholinguistic nature can bring about some debatable issues concerning 'scientific discourse'. 
At present the political, economic, cultural and scientific contacts between different countries are increasing faster than ever. Today the world needs a 'global' international language that can serve not only as a means of communication 'in general' to realize everyday communication but, also as a 'tool of their trade' for the specialists of different spheres of science and technology. ${ }^{3}$ In fact, it is a professionally-oriented international scientific language, in other words, a language for specific purposes.

It is obvious that today the leading candidate to hold the position of an international language is English. In 1977 it was calculated that the 4/5 of the world's publications written in the language of science were in English. ${ }^{4}$ It is also an acknowledged fact that the role of International English at present is of paramount importance because it is mainly due to international communication that the countries of the world may succeed in deepening their contacts to pave a path for democracy, technological progress, integration into different activities for the sake of mutual understanding, assistance and coexistence.

Consequently, the question of teaching/learning English as an international language becomes more essential, especially nowadays, because most of the newlyindependent, developing countries that are trying to build a stable, successful and healthy society have to communicate mainly in English. With the incredible progress we have in science and technology today, learning a language for specific purposes comes to the fore. If the command of English of modern specialists is confined only to the knowledge of 'general language', they will have great difficulties in their professional communication.

To use a foreign language as a means of effective international professional communication, one must necessarily get acquainted with the basic language of his/her profession as well, in other words, with the variety of the language that this or that specialist can use for specific purposes. In fact, such language can be very helpful for the specialists of all the countries to walk side by side in the world of science, share thoughts on their professional experience and find the wisest solutions to the global problems of today and tomorrow.

Thus, it is necessary that the specialists become proficient in this register of English as it will help them avoid any misunderstanding when discussing professional topics at international conferences, disputes, round-tables or seminars. The specialists will be able to exchange their professional experience with colleagues from other countries, write articles on the latest achievements in science, do research work (possibly a joint one as well), get information or just follow the progress in their field of science.

Teaching and learning Academic English as a means of international scientific communication presupposes not only a thorough investigation of the linguistic peculiarities of natural human language, but also a good choice of lexical and grammatical means of language. Such a register (a variety related to a particular use of the language, a particular subject or occupation $)^{5}$ will serve as a kind of language 
appropriate for 'specific' use. ${ }^{6}$

It follows logically from what has been said that this special register (or functional style) can be recommended as highly effective in terms of LSP teaching/learning, as the elaboration of 'this special register' will provide the learner with proper linguistic experience to realize both the purposes of everyday and professionally-oriented communication. ${ }^{7}$ To master such a register, it is necessary that a sufficient amount of pragmatically-oriented material be worked out which, in its turn, has to be combined with the learner's knowledge of English 'in general'. Thus, on the basis of these two factors a special register, that of Academic English, can be formed which will serve as a universal or international scientific language - a means of communication for educated people.

In this respect some linguists state that such register of Academic English becomes something like a 'shared code' between the members of both written and oral communication, in other words a 'shared code' between the writer and the reader or the speaker and the listener. ${ }^{8}$

Finally, it can be concluded from what has been said above that, as a kind of LSP, Academic English can serve as a special type of scientific language or as a means of communication among the scientists of the $21^{\text {st }}$ century. In fact, it can serve as an international language of science in 'scientific discourse'. In this respect it should also be stated that the thorough investigation of the correlation of the linguistic units of the system of language and speech acquires a role of crucial importance because such kind of special language can serve as a 'shared code' for the members of international communication.

\section{References:}

1. Reeves Carol. The Language of Science. London and New-York, 2005.

2. Ibid.

3. Михайловская Н.Г. О теоретических и практических задачах изучения русского языка как средства межнационального овщения. // Вопросы языкознания 1983, № 5; Gvishiani Natalya. Terminology in English Language Teaching. Москва, 1993; Crystal David. English as a Global Language. Cambridge, 2003.

4. Рождественский Ю.В. Послесловие. // Текстология английской научной речи. / Под ред. М.М. Глушко, Ю.А. Карулина. М., 1978; Fishman Joshua А., Cooper Robert L., Conrad Andrew W. The Spread of English. London, 1977.

5. Strevens Peter. New Orientations in Teaching of English. Oxford, 1978.

6. Halliday M. A. K. McIntosh A. and Strevens P. The Linguistic Sciences and Language Teaching. London, 1966. 
7. Gvishiani N. Terminology in English Language Teaching. M., 1993.

8. Magidova I. The Pragmalinguistic Register of English: The Theory and Practice. Doctoral Thesis, MGU, 1989; Gasparyan S.K. ESP as an Object of LearnerOriented Teaching. // Didaktik und Methodik des Fremdsprachenunterrichts. Bonn, Heft-4, July, 1998.

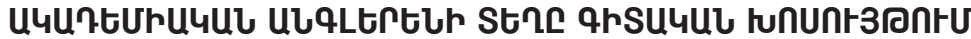

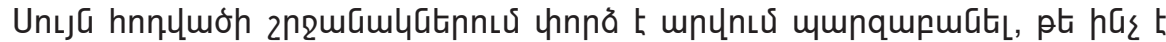

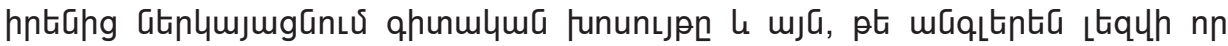

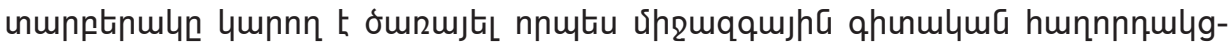
vima úp?ng: 